\title{
A Review of Carbonated Reactive MgO-stabilized Soil
}

\author{
Zhiheng Shang ${ }^{1}$, Guangyin $\mathrm{Du}^{1, *}$, Dingwen Zhang ${ }^{1}$, Songyu $\mathrm{Liu}^{1}$, Qian $\mathrm{Guo}^{1}$, Han Xia ${ }^{1}$ and Xingchen Qian $^{1}$ \\ ${ }^{1}$ Department of Underground Engineering, Southeast University, 211189, Nanjing, China
}

\begin{abstract}
The application of new reactive magnesium oxide $(\mathrm{MgO})$ binder in ground improvement has become a research hotspot. This paper summarized the latest research about the mechanical property potential of carbonated reactive MgO-stabilized Soil, described the electrical characteristics and permeability characteristics of solidified soil research results, analyzed the durability and corrosion resistance of solidified soil research, introduced the exploration of new curing agent engineering application measures. In view of the existing studies, further research about the relationship between the indicators of carbonation and unconfined compressive strength (UCS) were suggested, comprehensively study the corrosion resistance of the solidified soil, systematically study the reaction mechanism of fly ash with reactive $\mathrm{MgO}$, and improve the field test of reactive $\mathrm{MgO}$-carbonized mixing piles have been suggested.
\end{abstract}

\section{Introduction}

Cement (or lime) mixed with weak soil is applied widely in ground improvement. However, there exist such defects as serious pollutant and greenhouse gas emission in the production process, high energy consumption, slow curing and poor durability. John Harrison [1] created a new kind of reactive magnesia $(\mathrm{MgO})$ cement which could strengthen soil by absorbing carbon dioxide $\left(\mathrm{CO}_{2}\right)$. Vandeperre et al [2] proved that cement and reactive magnesia hydrate independently. The hydration product of the latter can achieve better curing effect after sufficient carbonation. Yi [3] clarified that the maximum UCS of MgO-solidified silt can reach $5 \mathrm{MPa}$ after $3 \mathrm{~h}$ carbonation, which of $\mathrm{MgO}$-solidified silty clay can reach 2.6 MPa after 24h carbonation. Liu [4] investigated the microscopic mechanism of MgOcarbonated soil and clarified that hydration products include prismatic nesquehonite $\left(\mathrm{MgCO}_{3} \cdot 3 \mathrm{H}_{2} \mathrm{O}\right)$ and flaky hydromagnesite $\left(\mathrm{Mg}_{5}\left(\mathrm{CO}_{3}\right)_{4}(\mathrm{OH})_{2} \cdot 4 \mathrm{H}_{2} \mathrm{O}\right)$ / dypingite $\left(\mathrm{Mg}_{5}\left(\mathrm{CO}_{3}\right)_{4}(\mathrm{OH})_{2} \cdot 5 \mathrm{H}_{2} \mathrm{O}\right)$ fill the soil pores to enhance the strength. Yi [3] discovered the application of carbonized mixing piles can reduce almost $90 \%$ of curing time, $65 \%$ of energy consumption and $77 \%$ of $\mathrm{CO}_{2}$ emission than cement mixing piles.

Recently, new founds have been obtained in the investigation of reactive $\mathrm{MgO}$ binder. This paper will review and summarize the research progresses in the following aspects: Physical and mechanical characteristics with influencing factors; Stability and corrosion resistance; Micro-mechanism; Engineering application tests.

\section{Research progress on physical and mechanical characteristics}

\subsection{Mechanics indicators}

Previous tests have proved that the UCS of carbonated reactive $\mathrm{MgO}$-stabilized Soil is higher than that of cement-solidified soil. However, the UCS showed different variation patterns for different $\mathrm{MgO}$ activities, dosage, water content and other factors. Different consolidation results appeared between silt and silty clay. Meanwhile, the new study also focuses on $\mathrm{E}_{50}$, the secant modulus when the stress is $50 \%$ of the peak, which is an important indicator of brittleness or plasticity, and reflects the resistance to elastic-plastic deformation, as Table 1. shows.

Furthermore, it can be concluded that:

(1) For silt, failure strain and deformation modulus E50 are not significantly different from that of cement solidified soil, which meet the soil deformation requirements. However, reactive $\mathrm{MgO}$ binder takes into action much more rapidly than cement.

(2) Previously, the effects of activity, dosage and initial water content on curing effect, especially unconfined compressive strength, were studied separately. At present, studies on the activity index $\mathrm{C}_{\mathrm{A}}$ and the ratio of dew-water cement $\mathrm{w} 0 / \mathrm{c}$ have revealed the relationship between these four indicators.

Liu proposed a fitting formula about qu related with $\mathrm{C}_{\mathrm{A}}$ and $\mathrm{w}_{0} / \mathrm{c}$ :

$q_{u}=\left(0.224 C_{A}-12.8\right) \times\left(w_{o} / c\right)^{-0.0326 C_{A}-0.0256}, R^{2}=0.97$

Cai [8] clarified another formula:

$q_{u}=\left(21.8 C_{A}-12.5\right) \times\left(w_{0} / c\right)^{-3.6 C_{A}+0.25}, R^{2}=0.95$

\footnotetext{
"Corresponding author: guangyin@seu.edu.cn
} 
Table 1. Summary of the latest mechanical experiments

\begin{tabular}{|c|c|c|c|}
\hline Content & Phenomenon & Analysis & Sources \\
\hline $\begin{array}{l}\text { Activity of } \\
\mathrm{MgO}\end{array}$ & $\begin{array}{l}\text { The UCS of sample MgO-A after } 3 \mathrm{~h} \text { of } \\
\text { carbonation was significantly higher } \\
\text { than cement soil-solidified after } 28 \mathrm{~d} \text { and } \\
\text { low activity } \mathrm{MgO}-\mathrm{B}\end{array}$ & $\begin{array}{l}\mathrm{MgO} \text { with low activity inhibits } \\
\text { cementation and promotes fracture } \\
\text { development. }\end{array}$ & [5] \\
\hline $\begin{array}{l}\text { The } \\
\text { compression } \\
\text { feature }\end{array}$ & $\begin{array}{l}\text { (1) The compressibility of sludge } \\
\text { decreased when the } \mathrm{MgO} \text { content is } \\
\text { higher than } 6 \% \text {. } \\
\text { (2) The consolidation yield stress and } \\
\text { yield strength increase with } \mathrm{MgO} \\
\text { content. } \\
\text { (3) The compression modulus Es of the } \\
\text { high-content MgO samples had a peak } \\
E_{\text {Sp. }}\end{array}$ & $\begin{array}{l}\text { The carbonation of the samples with } \\
\text { high content produces cementing } \\
\text { material, which leads to the increase of } \\
E_{\mathrm{S}} \text { due to compaction, while the } \\
\text { carbonation of the samples with low } \\
\text { content causes structural deficiency, and } \\
\text { the increase of } E_{\mathrm{S}} \text { is mainly provided by } \\
\text { the compaction of soil particles. }\end{array}$ & [6] \\
\hline $\begin{array}{l}\text { Secant modulus } \\
\mathrm{E}_{50}\end{array}$ & $\begin{array}{l}\text { The failure strain ranges between } 0.8 \% \\
\text { and } 1.6 \% \text {, which is close to the cement- } \\
\text { sample. } q_{\mathrm{u}} \text { and } E_{50} \text { ratio in the range of } \\
60-200 \text {, close to the cement soil. }\end{array}$ & No explanation. & [7] \\
\hline $\begin{array}{l}\text { Activity index } \\
\mathrm{C}_{\mathrm{A}} \& \text { quasi- } \\
\text { water-cement } \\
\text { ratio } \mathrm{w}_{0} / \mathrm{c} \\
\end{array}$ & $\begin{array}{l}\text { (1) } q_{\mathrm{u}} \text { increased with the increase of } C_{\mathrm{A}} \\
\text { and the decrease of } w_{0} / c \text {. } \\
\text { (2) The ratio of } E_{50} \text { to } q_{\mathrm{u}} \text { is about } 35-150 \text {. }\end{array}$ & $\begin{array}{l}\text { Lower } C_{\mathrm{A}} \text { leads to incomplete hydration } \\
\text { and limited cementing ability. Increasing } \\
C_{\mathrm{A}} \text { or decreasing } w_{0} / c \text { can promote the } \\
\text { formation of nesquehonite. }\end{array}$ & [8] \\
\hline
\end{tabular}

However, now it is still not possible to establish a quantitative relationship with some other factors that can affect curing, such as soil particle gradation, pore distribution and initial dry density.

\subsection{Physical properties}

In recent years, the research on solidified soil has been increasingly perfect, and new progress has been made in terms of the electrical characteristics, permeability and other physical properties of solidified soil.

Cai [7] studied the change rule of resistivity and conductivity of reactive $\mathrm{MgO}$-solidified samples. The results show the resistivity increased significantly while the UCS increased linearly with the resistivity. What's more, the conductivity of pore fluid decreased first and then increased with the initial water content, similar to the change law of $\mathrm{pH}$. He predicted that Brucite $\left(\mathrm{Mg}(\mathrm{OH})_{2}\right)$ and the carbonized product crystals block the current flow. OH- conducts electricity easily, but the carbonized products are difficult to ionize. Water hinders transport and carbonation of $\mathrm{CO}_{2}$, thus increasing $\mathrm{pH}$ and conductivity.

Wang [9] pay attention to the Permeability of reactive $\mathrm{MgO}$-solidified samples and found it is Similar with cement-solidified soil. Hydraulic conductivity K of silty clay increased with the carbonation time, while the $\mathrm{K}$ of silt decreased first and then increased. It was predicted that high $\mathrm{CO}_{2}$ pressure helps produce splitting and expanding soil pores, but helps to increase the rate of carbonation in the other hand. High water content helps $\mathrm{MgO}$ to be fully hydrated, but it hinders penetration of $\mathrm{CO}_{2}$ and forms water film on the surface of $\mathrm{Mg}(\mathrm{OH})_{2}$.

It can be concluded that:
(1) There is a good linear relationship between the unconfined compressive strength and resistivity of $\mathrm{MgO}$ solidified silty clay. At the same time, resistivity can reflect the initial water content and $\mathrm{pH}$ of soil. Therefore, it is proved that the resistivity method is theoretically feasible to predict the strength of $\mathrm{MgO}$-solidified soil.

(2) Both $\mathrm{MgO}$-solidified silt and silty clay have good impermeability, which can be tried to be applied to the in-situ isolated restoration of contaminated sites. However, the corrosion resistance and stability of $\mathrm{MgO}$ solidified soil need to be further studied.

\section{Research progress on stability and corrosion resistance}

Previously, preliminary studies on the stability and corrosion resistance of carbonated reactive $\mathrm{MgO}$ stabilized Soil have been carried out by some scholars. Liska \& Al-Tabbaa [10] proved that the strength of reactive $\mathrm{MgO}$ cement block was stable at $80^{\circ} \mathrm{C}$. Although the resistance to hydrochloric acid is slightly lower than that of cement, the resistance to sulfuric acid is stronger. In recent years, further studies in this field have revealed more stable and anti-corrosion properties of the new binder curing soil, as Table 2. shows.

Through the above research, it can be concluded that:

(1) The freeze-thaw cycling resistance of the reactive $\mathrm{MgO}$-solidified soil is similar to that of the cementsolidified soil, and the drying-wetting cycling resistance of the solidified silt is even better. However, the dryingwetting cycling resistance of the solidified silty clay is relatively poor.

(2) The sulfate resistance of reactive $\mathrm{MgO}$-solidified soil is superior to that of ordinary cement-solidified soil. Combined with the excellent impermeability proved in 
Table 2. Summary of the latest experiments about stability and corrosion resistance

\begin{tabular}{|c|c|c|c|c|}
\hline Content & Method & Phenomenon & Analysis & Sources \\
\hline $\begin{array}{l}\text { Freeze- } \\
\text { thaw cycle } \\
\text { characteri- } \\
\text { stics }\end{array}$ & $\begin{array}{l}\text { (1) } 1 \mathrm{~d} \text { curing; } \\
\text { (2) } 24 \mathrm{~h} \text { curing in } \\
23^{\circ} \mathrm{C} \text {; } \\
\text { (3) } 23 \mathrm{~h} \text { standard } \\
\text { curing; } \\
\text { (4)Repeated } 10 \\
\text { times. }\end{array}$ & $\begin{array}{l}\text { The water content and mass of cement } \\
\text { samples decreased faster than that of } \\
\mathrm{MgO} \text { samples, the quality of silt samples } \\
\text { decreased faster than that of silty clay } \\
\text { samples. }\end{array}$ & $\begin{array}{l}\text { The freezing-thaw } \\
\text { cycle has no } \\
\text { significant effect on } \\
\text { the material } \\
\text { composition and } \\
\text { microstructure. }\end{array}$ & [11] \\
\hline $\begin{array}{l}\text { Drying- } \\
\text { wetting } \\
\text { cycle } \\
\text { characteri- } \\
\text { stics }\end{array}$ & $\begin{array}{l}\text { (1) } 1 \mathrm{~d} \text { curing; } \\
\text { (2) } 48 \mathrm{~h} \text { curing in } \\
30^{\circ} \mathrm{C} \text {; } \\
\text { (3) } 23 \mathrm{~h} \text { curing in } \\
\text { water; } \\
\text { (4) Repeat for } 28 \mathrm{~d} \text {. } \\
\text { (1) } 1 \mathrm{~d} \text { curing; }\end{array}$ & $\begin{array}{l}\text { (1)The residual strength of the silt } \\
\text { samples decreased by only } 10 \% \text {, but that } \\
\text { of silty clay samples decreased by } 65 \% \text {; } \\
\text { (2)Compared with cement sample, silt } \\
\text { sample } \mathrm{E}_{50} \text { increased by } 50 \% \text {, while silty } \\
\text { clay sample } \mathrm{E}_{50} \text { was less than } 50 \% \text {. } \\
\text { (1)Carbonized sample slightly }\end{array}$ & $\begin{array}{l}\text { The pore accumulation } \\
\text { increases significantly, } \\
\text { resulting in a decrease } \\
\text { in strength. The } \\
\text { drying-wetting cycle } \\
\text { resistance is weaker. } \\
\mathrm{SO}_{4}^{2-} \text { reacts with } \mathrm{Ca}^{2+}\end{array}$ & [12] \\
\hline $\begin{array}{l}\text { Sulfate } \\
\text { resistance }\end{array}$ & $\begin{array}{l}(2) \mathrm{Immerse} \text { in } \\
50 \mathrm{~g} / \mathrm{L} \mathrm{Na}_{2} \mathrm{SO}_{4} \\
\text { solution and } \\
\mathrm{MgSO}_{4} \text { solution } \\
\text { respectively. }\end{array}$ & $\begin{array}{l}\text { peeled, cement sample cracked and } \\
\text { expanded seriously; } \\
\text { (2)The strength of carbonized samples } \\
\text { basically unchanged, while that of } \\
\text { cement samples reduced by } 60 \% \text {. }\end{array}$ & $\begin{array}{l}\text { in cement to form } \\
\text { ettringite } \\
\left(3 \mathrm{CaO} \cdot \mathrm{Al}_{2} \mathrm{O}_{3} \cdot 3 \mathrm{CaSO}_{4} \text {. }\right. \\
\left.32 \mathrm{H}_{2} \mathrm{O}\right) \text {, causing } \\
\text { cracks as the volume } \\
\text { increases. }\end{array}$ & [13] \\
\hline $\begin{array}{l}\text { Immersio- } \\
\text { n stability }\end{array}$ & $\begin{array}{l}\text { (1)7d and } 28 \mathrm{~d} \\
\text { standard curing; } \\
\text { (2)Immerse in } \\
\text { water. }\end{array}$ & $\begin{array}{l}\text { (1)Carbonized samples kept intact, while } \\
\text { the non-solidified sludge began to } \\
\text { disintegrate after } 0.5 \mathrm{~h} \text {; } \\
\text { (2)The immersion stability of samples } \\
\text { with } \mathrm{MgO} \text { only is lower than that } \\
\text { containing fly ash. }\end{array}$ & $\begin{array}{l}\text { Fly ash particles fill } \\
\text { pores and form certain } \\
\mathrm{M}-\mathrm{S}-\mathrm{H} \text { with reactive } \\
\mathrm{MgO} \text { to play a } \\
\text { cementing role. }\end{array}$ & [14] \\
\hline
\end{tabular}

[9], the new reactive $\mathrm{MgO}$ binder can be applied to the in-situ isolation and remediation of sulphatecontaminated sites.

(3) The addition of fly ash is beneficial to give full play to the cementing and compaction of hydrated carbonation products of reactive $\mathrm{MgO}$ binder. However, the reaction mechanism between fly ash and reactive $\mathrm{MgO}$ binder is still unclear.

\section{Research progress on micro- mechanism}

The Micro-mechanism models for silty clay and silty clay were proposed by Cai $[15,16]$ as the following fig. 1 . shows. Prismatic nesquehonite was formed within carbonized silt to increase strength significantly. It can be converted into hydromagnesite and dypingite which can be harder but lead to a decrease in strength because of shape and new cracks.

Compared with silt, reactive $\mathrm{MgO}$ in silty clay samples tightly encapsulates the soil aggregates and consolidates them to reduce internal pores to gains strength growth as fig.2. shows.

Based on these studies about silt and silty clay, Wang [17] clarified the Micro-mechanism model for reactive MgO-solidified sludge about immersion stability, freezethaw cycle characteristics and drying-wetting cycle characteristics as fig.3. shows.

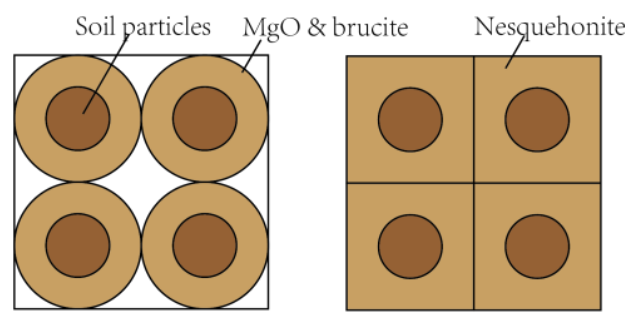

(a) Hydration

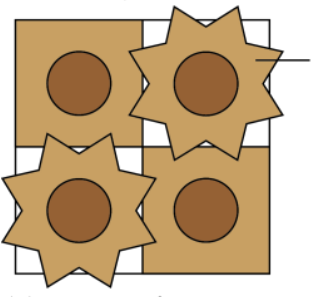

(c) Over-carbonation (b) Carbonation

Hydromagnesite \& dypingite
Fig. 1. Micro-mechanism model of carbonated reactive $\mathrm{MgO}$ stabilized silt[15]

When undergoing the immersion tests and the drying-wetting cycle tests, nesquehonite, hydromagnesite and dypingite can convert to each other:

$$
\begin{array}{r}
\mathrm{Mg}_{5}\left(\mathrm{CO}_{3}\right)_{4}(\mathrm{OH})_{2} \cdot 4 \mathrm{H}_{2} \mathrm{O}+\mathrm{Mg}_{5}\left(\mathrm{CO}_{3}\right)_{4}(\mathrm{OH})_{2} \cdot 5 \mathrm{H}_{2} \mathrm{O}+15 \mathrm{H}_{2} \mathrm{O} \\
\leftrightarrows 8 \mathrm{MgCO}_{3} \cdot 3 \mathrm{H}_{2} \mathrm{O}+2 \mathrm{Mg}(\mathrm{OH})_{2}
\end{array}
$$




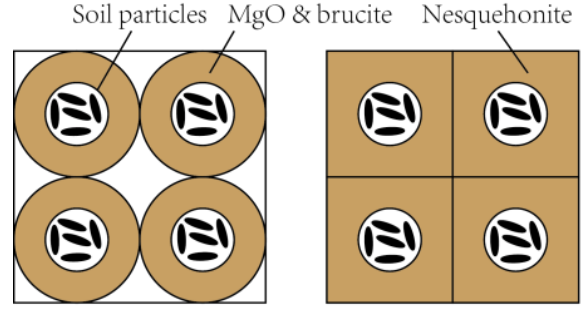

(a) Hydration

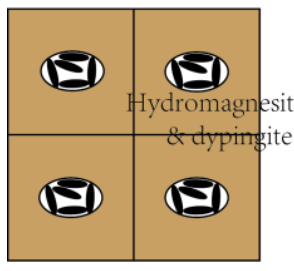

(c) Squeeze the pore

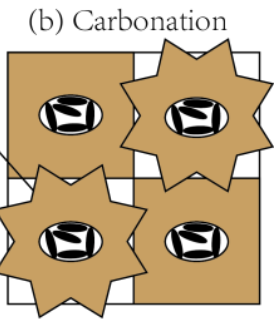

(d) Over-carbonation

Fig. 2. Micro-mechanism model of carbonated reactive $\mathrm{MgO}$ stabilized silty clay[16]

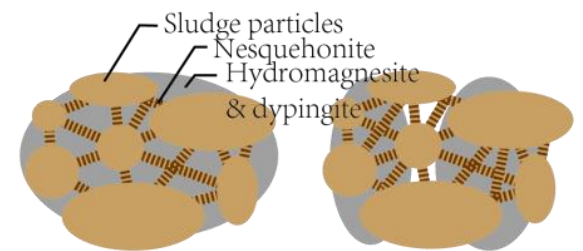

(a) Carbonation

(b) Immersion
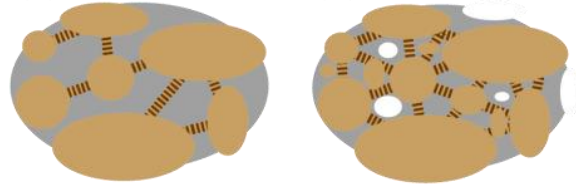

(c) Dehydration

(d) Freeze-thaw cycle

Fig. 3. Durability Micro-mechanism model of carbonated reactive $\mathrm{MgO}$-stabilized sludge[17]

During the freeze-thaw cycle, although the material and microstructure change slightly, a few holes appear on the surface due to the water hiding in samples. Zheng [11] clarified a decrease of UCS because of these holes in silt and silty clay samples. However, Wang believes the dislocation of soil particles induced by freezing-thaw cycle improves the particles structure which leads to higher strength.

\section{Exploration of engineering application}

To use reactive $\mathrm{MgO}$ binder in ground improvement appeared in engineering activities. Liu [18] used the manual excavation method in the laboratory carbonation stirring pile test. The experimental data show that the optimum initial water content is $15 \%$. What's more, the strength of the carbonized piles increases with the increase in $\mathrm{CO}_{2}$ ventilation pressure. However, in this study, the $\mathrm{CO}_{2}$ ventilation pressure was limited to 25 $200 \mathrm{kPa}$, and it was hard to proved that excessive $\mathrm{CO}_{2}$ ventilation pressure would have any negative effect on the carbonized piles. In addition, there was no comparison test on soil type, curing time and other variables.
Cai [19] attempted to use $\mathrm{CO}_{2}$ foam method to reinforce weak foundation soil in view of the difficulty in effectively permeating $\mathrm{CO}_{2}$ in field application. The $200 \mathrm{kPa} \mathrm{CO}_{2}$ was injected into sodium dodecyl benzene sulfonate (SDBS, $\mathrm{C}_{18} \mathrm{H}_{29} \mathrm{NaO}_{3} \mathrm{~S}$ ) for foaming, and then the foam was mixed with soil, water and reactive $\mathrm{MgO}$ for carbonation. After carbonation, the water content and $\mathrm{pH}$ of the sample decreased, which proved that $\mathrm{CO}_{2}$ in the foam could react with $\mathrm{Mg}(\mathrm{OH})_{2}$. However, the UCS did not increase more than $200 \mathrm{kPa}$, so the application effect could not be achieved. This may be due to the low amount of $\mathrm{CO}_{2}$ in the foam, the high initial water content of the sample caused by foaming agent, and the dispersion of $\mathrm{CO}_{2}$ in the sample preparation process. Therefore, the $\mathrm{CO}_{2}$ foam method still needs to be further studied.

\section{Conclusion}

(1) Compared with cement, reactive $\mathrm{MgO}$ binder has advantages of fast curing, high stability and strong corrosion resistance, which has obvious advantages in solidified soil mixing piles and isolating polluted sites. It is better to work together with fly ash, so exploring the effect of more industrial waste slag such as calcium carbide slag should be considered.

(2) At present, the engineering application focus on ventilation while the foam method meets problems. Developing dry ice carbonization method may be a possible choice. Consideration should also be given to the use of industrial $\mathrm{CO}_{2}$ emissions to reduce costs and protect the environment.

(3) Simulation study on $\mathrm{CO}_{2}$ migration and reaction in solidified soil was still lacking. The effect of reactive $\mathrm{MgO}$ binder on the surrounding ecosystem is unclear. Further experimental studies need to be considered.

\section{References}

1. A. J. W. Harrison. United States Patent, 7347896 (2008)

2. L. J. Vandeperre, M. Liska, A. Al-Tabbaa. Cem. Concr. Compos., 30, 706 (2008)

3. Y. Yi. Sustainable novel deep mixing methods and theory. Southeast University (2013)

4. S. Liu, C. Li. Chin. J. Geotech. Eng., 37, 148 (2015)

5. G. Cai, S. Liu, Y. Du, et al. J. Southeast Univ. (Chin. Ed.), 45, 958 (2015)

6. H. Wang, D. Wang, Y. He. J. Cent. South Univ. (Sci. Technol.), 48, 2133 (2017)

7. G. Cai, S. Liu, J. Cao. China J. Highw. Transp., 30, 18 (2017)

8. G. Cai, S. Liu, Y. Du, et al. J. Mater. Civ. Eng., 29 (2017)

9. L. Wang, S. Liu, G. Cai, et al. Chin. J. Geotech. Eng., 40, 953 (2018)

10. M. Liska, A. Al-Tabbaa. Adv. Cem. Res., 24, 221 (2012) 
11. X. Zheng, S. Liu, G. Cai, et al. J. Southeast Univ. (Chin. Ed.), 45, 595 (2015)

12. X. Zheng, S. Liu, G. Cai, et al. Chin. J. Geotech. Eng., 38, 297 (2016)

13. S. Liu, X. Zheng, G. Cai, et al. Rock Soil Mech., 37, 3057 (2016)

14. D. Wang, H. Wang. J. Xiao. J. Zhejiang Univ., Eng. Sci., 52, 719 (2018)

15. G. Cai, S. Liu, J. Cao. China Civil Engineering Journal., 50, 105 (2017)
16. S. Liu, J. Cao, G. Cai. Rock Soil Mech., 39, 1543 (2018)

17. D. Wang, J. Xiao, L. Li, et al. Rock Soil Mech., 40, 3045 (2019)

18. S. Liu, G. Cai, G. Du, et al. Chin. J. Geotech. Eng., 39, 136 (2017)

19. G. Cai, S. Liu, Z. Zhang, et al. Chinese Journal of Underground Space and Engineering, 11, 34 (2015) 